\title{
Investigating the Impacts of Real Exchange Rates on Economic Growth: A Case study of South Africa.
}

\author{
Kin Sibanda \\ Department of Economics, University of Fort Hare \\ (Corresponding Author) Email: keith08.kin@gmail.com \\ Ronney Ncwadi \\ Department of Economics, University of Fort Hare \\ Email: rncwadi@ufh.ac.za

\section{Courage Mlambo} \\ Department of Economics, University of Fort Hare \\ Email: mlamboct@gmail.com
}

Doi:10.5901/mjss.2013.v4n13p261

\section{Abstract}

This paper examines the impact of real exchange rates on economic growth in South Africa. The paper uses quarterly time series data for the period of 1994 to 2010. The Johansen cointegration and vector error correction model is used to determine the impact of real exchange on economic growth in South Africa. The explanatory variables in this paper are real exchange rates, real interest rates, money supply, trade openness and gross fixed capital formation. Results of the study reveals that real exchange rates have a dampening long run impact on economic growth in South Africa. From the regression results, it is noted that undervaluation of the currency significantly hampers growth in the long run, whilst it significantly enhances economic growth in the short run. As such, the policy of depreciating exchange rates to achieve higher growth rates is only effective in the short run and is not sustainable in the long run. Based on the findings of this study, the authors recommend that misalignment (overvaluation and undervaluation) of the currency should be avoided at all costs. In addition, the results of the study shows that interest rates also have a significant impact on growth and since interest rates have a bearing on the exchange rate, it is recommended that the current monetary policy of inflation targeting be maintained in South Africa.

Keywords: Real exchange rates, Economic growth, Vector Error Correction Modeling, South Africa.

\section{Introduction}

South Africa's fiscal discipline and relatively conservative economic policy since 1994 have failed to produce the expected results for growth and employment (Rodrik, 2008). In view of the policy framework adopted by the South African government, it is appropriate to ask how this has transformed the wellbeing of the economy. High levels of unemployment and sluggish economic growth can be recognised as vexing problems that have challenged South Africa even sixteen years into democracy ${ }^{1}$. In light of the government's exchange rate policy over the years, the questions that basically come to mind concern the performance of the economy in relation to economic growth and unemployment. Does the exchange rate matter in South Africa when it comes to improving economic growth and alleviating unemployment? What are the consequences of a stronger or weaker rand on the economy? This paper aims to provide answers to these questions by examining the impact of real exchange rate on economic growth in South Africa.

The relationship between the real exchange rate and economic growth is fast becoming an important area of study in both the developing and developed countries (Akpan, 2008). Edwards and Garlick (2007) assert that the exchange rate plays a central role in public debate around trade and trade policy in South Africa, with widespread calls for appreciation, depreciation or simple stabilization. Rodrick (2007) concurs that economists have long known that poorly

1 "South Africa's unemployment rates have increased rapidly since the move to democracy and are now higher than they were in 1993 "( Nchimunya, 2011). 
managed exchange rates can be disastrous for economic growth. The real exchange rate thus, serves as an international price for determining the competitiveness of a country. Takaendesa (2006) explains that the real exchange rate plays a crucial role in guiding the broad allocation of production and spending in the domestic economy between foreign and domestic goods.

From 1994, South Africa has been suffering from high inflation levels, declining output and unemployment. In an attempt to ensure price stability, the monetary authorities adopted the inflation targeting regime to keep inflation parity with its major trading partners. This therefore, meant that the country abandoned the fixed exchange rate regime for a market-based, free floating exchange rate (Van der Merwe, 1996). The adoption of a free float exchange rate system exposed the economy to the dangers of exchange rate misalignment. Misalignment according to Montiel and Serven (2008) is the deviation of the actual or observed real exchange rate from the equilibrium real exchange rate. Misalignment can either be an overvaluation or undervaluation of the currency. Developing countries are often guilty of the latter, which negatively affects the export sector and ultimately economic growth. With regard to this, Takaendesa (2006) argues that emerging economies in particular, are encouraged to conduct their policies so as to get this macroeconomic relative price right; that is, an exchange rate that does not stray too far from its equilibrium value.

\section{An Overview of the Real Exchange Rates and Economic Growth in South Africa}

The level of real exchange rate is important on economic growth as it determines the value of imports and exports of a country. Walters and De Beer (1999) explain that a country's exchange rate is an important determinant of the growth of its cross-border trading and it serves as a measure of its international competitiveness. Figure 1 below shows the trends of real effective exchange rate and economic growth over the period 1994-2010.

Figure 1: Trends in real effective exchange rates and Real GDP in South Africa 1994-2010

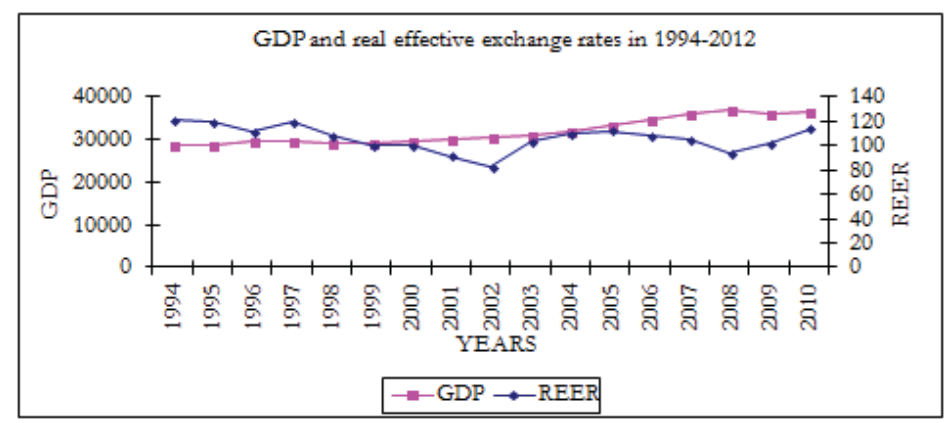

Source: Data compiled from SARB and DTI, (2012)

The movements in both economic growth as represented by gross domestic product and real effective exchange rate have been used to analyse the relationship between the two. From Figure 1 it can be noted that over the period 19942010, economic growth trends were fairly stable as compared to volatile real exchange rates. Between 1994 and 1995 the rand exchange was fairly stronger followed by a sharp depreciation notably in 1996 where the real effective exchange rate of the rand was at a low of 111.86. During this period, economic growth in million rands was stable but increasing from R28536 million in 1994 to R29431 million in 1996. The economic performance of the post-apartheid economy has been quite strong, averaging growth in real gross domestic product (GDP) of 3.3 percent and 1.35 percent in per capita terms for the period 1995 to 2005. This growth trend was an improvement, if compared with the rates of the 1985 to 1994 period, where the respective average rates were 0.8 and -1.3 percent. Du Plessis and Smit (2007) argue that the improved growth performance is largely attributable to strong domestic demand and a large foreign capital inflow in the face of low inflation and interest rates. The recovery continued between 1995 and 1997 where growth rates of 3.1 per cent, 4.3 per cent and 2.6 per cent were recorded, respectively. In the year 1997 there was a sharp appreciation as shown by a change in the REER from 111.86 in 1996 to 119.22 in 1997. The resulting change was accompanied by a sharp drop in GDP to 2.6 per cent from 4.3 per cent in 1996. Du Plessis and Smit (2007) attribute this to the effects of the global financial crisis. Also the Asian financial crisis and the world recession contributed to this dismal performance. 
There was a sharp depreciation in 1998 as shown by the change in the REER to 108.05 and economic growth responded by dropping to R29116 million. A weaker rand was persistent from 1998 to 2002, and during this time economic growth was fairly stable and rising save for the year 2001.

A massive appreciation in 2003 was accompanied by a decrease in economic growth, that is, in 2002 the REER was at 82.55 and 103.23 in 2003 and economic growth was R30581million and R30992 million respectively. From 2004 to 2008 the rand exchange took a downward trend whilst economic growth increased slightly year on year save for 2008. In 2009 and 2010 the rand was stronger and economic growth was low especially in 2009 where GDP growth took a negative swing from R36942 million in 2008 to R35936 million in year 2009. Year 2010 experienced a further appreciation of REER to 113.89 from 101.41 in 2009. This was accompanied by a slight increase in growth to R36594 million.

\section{A Review of Relevant Literature}

Theories and empirical evidence present different conclusions regarding the relationship between economic growth and exchange rates. The existing discourse about the impact of real exchange rate strength in South Africa has its foundation in the contest between the views of the Washington Consensus versus Rodrik's (2007) conclusions ${ }^{2}$ (Mishi, 2011). These contrasting views have their foundation in theoretical literature. The traditional approach to exchange rate holds that devaluation has expansionary effects on the economy (Salvatore, 2005). The Structuralist approach to exchange rates, on the other hand, is equally convincing that devaluation is contractionary to expansion in the economy (Acar, 2000). The Balassa-Samuelson Hypothesis holds that there is a positive correlation between exchange rates and growth.

The reviewed studies in the developed countries are inconclusive about the impact of exchange rate on economic growth. The empirical literature from developed nations show mixed results about the impact of real exchange rates on economic growth. Chen (2012) for example concurred with the Balassa-Samuelson hypothesis that there is a positive effect of exchange rates on economic growth. Razin and Collins (1997) on the other hand found that currency overvaluations are associated with lower growth which is consistent with the traditional approach to exchange rates. Jaussaud and Rey (2009) also confirmed the traditional approach in that Japanese exports to China and United States were found to decline if currency appreciated. This in turn affected growth negatively. Vieira and MacDonald (2010) findings were that a more depreciated (appreciated) real exchange rate helps (harms) long-run growth.

The review of literature from developing countries also presents mixed results, for instance, Tarawalie (2010) and Akpan (2008) found a positive correlation between exchange rates and economic growth. These results support the Balassa-Samuelson hypothesis. Acar (2000) confirmed the Structuralist approach that devaluations may be contractionary to growth. Aguirre and Calderon (2005), Domac and Shabsigh (1999) are aligned to the traditional approach that devaluations enhance economic growth. McPherson, Rakovski and Kennedy (2000) however found no direct relationship between exchange rates and economic growth. Munthali et al. (2010) found out that exchange rate volatility has negative effects on growth.

Empirical literature on the impact of real exchange rate on economic growth in South Africa focused mainly on the impact of exchange rate volatility on exports, for instance, Todani and Munyama, 2005; Raddatz, 2008; Edwards and Garlick, 2007. The findings of these studies suggest that exchange rate volatility negatively affects exports in South Africa.

The lack of consensus in literature (both theoretical and empirical) justifies the contradictory calls by different stakeholders in the South African economy on how to deal with the buoyant Rand. The manufacturing sector (tradable goods sector), the monetary authorities and labour bodies like Congress of South African Trade Union- COSATU (concerned by high unemployment levels). The call to devalue the currency comes with some costs related to interference with the market forces. In the light of this information, the paper seeks to find out if the real exchange rates directly and strongly influence the level economic growth. Failure to find the true relationship might result in wrong policy formulations and resources wastage.

\section{Methodology}

The paper follows the cointegration and vector error correction modeling (VECM) of Johansen $(1991,1995)$ and it applies

${ }^{2}$ The Washington Consensus view holds that real exchange misalignment causes imbalances which are bad for growth, (Williamson, 2004). In contrast, Rodrik (2007) argues that "undervaluation relative to purchasing power parity is good for growth since it promotes the tradable sector and overvaluation destroys exports and hence economic growth". 
maximum likelihood estimation to a vector error correction (VEC) model to simultaneously determine the long run and short run determinants of the dependant variable in a model. Firstly data has to be integrated of the same order (Brooks, 2008). To achieve this, unit root tests to examine stationarity of data sets are carried out. In testing for the unit root properties of the time series data, the variables were subjected to the Augmented Dickey-Fuller (ADF) and Philips-Peron unit root test. The informal graphical method was also used to give a preliminary view of stationarity. The paper made use of diagnostic tests such as the residual normality test, heteroscedacity, autocorrelation tests and Ramsey test in order to validate the parameter estimation outcomes achieved by the estimated model.

This paper uses quarterly data covering the period 1994-2010. The data was obtained from the South African Department of Trade and Industry (DTI), the South African Reserve Bank (SARB) publications, and the South African Department of Statistics (StatsSA).

\subsection{The model}

In examining the impact of real exchange rates on economic growth in South Africa the explanatory variables in this paper are fixed capital formation (FCF), real interest rates (RIR) trade openness(OPEN), broad money supply $\left(\mathrm{M}_{3}\right)$ and real exchange rates (RER).

This paper modifies the model of (Acar, 2000). The reduced form equation for output in the model is formally specified below.

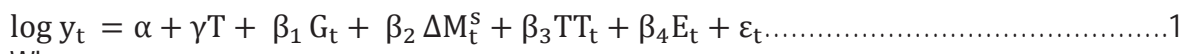

Where

$\mathrm{y}_{\mathrm{t}}$ : Real output ; $\alpha$ : Constant term; $\gamma$ : Parameter that captures the trend rate of growth; T: Time period; G: Relative size of government (the ratio of government expenditures to nominal output); $\mathrm{M}^{\mathrm{s}}$ : Money supply term (the difference between actual and expected rate of growth of nominal money supply); TT: Terms of trade; E: Real exchange rate and $\varepsilon$ : Error term with mean zero and constant variance.

The main objective of this paper is to investigate the impact of the real exchange rate on economic growth (GDP). An output growth model is thus specified by adding the real exchange rates (RER) to the set of explanatory variables. In this study, the dependent variable is economic growth(y) as explained by the movements in other variables which are real interest rate (RIR), fixed capital formation (FCF), broad money supply $\left(\mathrm{M}^{\mathrm{s}}\right)$, trade openness $(\mathrm{OP})$ and real exchange rates (RER) which is the main explanatory variable. The model is specified as follows:

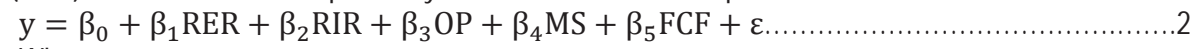

Where:

$\beta_{0}$ : The intercept; $\beta_{1}, \beta_{2}, \beta_{3}, \beta_{4}$ and $\beta_{5}$ : Coefficients of the explanatory variables; $\varepsilon$ : Error term which represents omitted variables in the specification of the model; Y: Real output; RER: The real exchange rates; RIR: is the real interest rates; OP: represents trade openness; $\mathrm{M}^{\mathrm{s}}$ : is broad money supply; FCF: represents fixed capital formation investment.

To obtain elasticity coefficients and remove the effect of outliers, the variables have to be transformed into natural logarithms. In log linear form the function becomes:

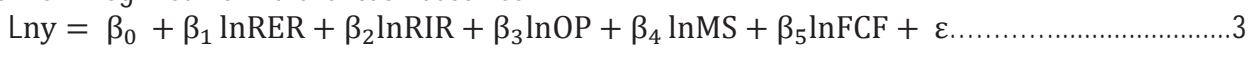

\section{Presentation and Analysis of Results}

This section is divided into five subsections. The unit root test is presented first, followed by cointegration tests. This leads to the presentation of the vector error correction model (VECM)results which is followed by diagnostic checks, impulsive response and variance decomposition.

\subsection{Testing for Stationarity}

The graphical results from the test for Stationarity are presented in Figure 2 and 3 (see appendix 1 and 2): Figure 2 shows data in level form and Figure 3 shows the first differenced data. The Augmented Dickey-Fuller and the PhillipsPeron test results are shown in Tables 1 and 2.

Using the graphical method, data that fluctuate around the zero mean indicate stationarity. It can be noted that Figure 2 shows series before differencing and hence are non-stationary as the mean is not zero. Figure 3, however, shows stationary series after differencing and the means are fluctuating around zero. It can, therefore, be concluded that 
Figure 3 shows stationary data after differencing. This implies that the data is stationary if integrated of order one. The first order integrated series according to (Gujarati and Porter, 2010) ensure that economic data is stationary for the purpose of avoiding spurious regressions. The informal method, however, is not enough to conclude that data is stationary as it is informal, hence the need for a more formal method to complement it. Consequently, other formal tests were conducted to support findings from the graphical findings. In this regard, the Augmented Dickey-Fuller and the Phillips-Peron tests were adopted and the results are presented in Tables 1 and 2 below.

Table 1. Stationarity results of the Augmented Dickey-Fuller test

\begin{tabular}{|c|c|c|c|c|}
\hline \multicolumn{5}{|c|}{ Augmented Dickey-Fuller } \\
\hline Order of integration & Variable & Intercept & $\begin{array}{c}\begin{array}{c}\text { Trend and } \\
\text { intercept }\end{array} \\
\end{array}$ & None \\
\hline Level & LGDP & 0.213 & -2.529 & 3.300 \\
\hline $1^{\text {st }}$ difference & DGDP & $-8.607^{\star \star \star}$ & $-8.641^{\star \star \star}$ & $-6.849^{\star \star \star}$ \\
\hline Level & LRER & -2.301 & -2.090 & -0.265 \\
\hline $1^{\text {st }}$ difference & DRER & $-6.308^{\star \star \star}$ & $-6.411^{\star \star \star}$ & $-6.359^{\star \star \star}$ \\
\hline Level & LRIR & -2.056 & -3.138 & -0.936 \\
\hline $1^{\text {st }}$ difference & DRIR & $-5.550^{\star \star \star}$ & $-5.573^{\star \star \star}$ & $-5.594^{\star \star \star}$ \\
\hline Level & LFCF & 0.082 & -1.543 & 2.374 \\
\hline $1^{\text {st }}$ difference & DFCF & $-5.048^{\star \star \star}$ & $-5.065^{\star \star \star}$ & $-4.206^{\star \star \star}$ \\
\hline Level & LMS & -0.077 & -9.839 & 0.361 \\
\hline $1^{\text {st }}$ difference & DMS & $-36.943^{\star \star \star}$ & $-41.179^{\star \star \star}$ & $-23.471^{\star \star \star}$ \\
\hline Level & LTO & -2.776 & -2.518 & 0.401 \\
\hline $1^{\text {st }}$ difference & DTO & $-5.711^{\star \star \star}$ & $-5.743^{\star \star \star}$ & $-5.735^{\star \star \star}$ \\
\hline $1 \%$ & \multirow{3}{*}{ Critical values } & -3.535 & -4.403 & -2.601 \\
\hline $5 \%$ & & -2.907 & -3.480 & -1.946 \\
\hline $10 \%$ & & -2.591 & -3.167 & -1.614 \\
\hline
\end{tabular}

Table 2. Stationarity results of the Phillips-Perron test

\begin{tabular}{|c|c|c|c|c|}
\hline \multicolumn{5}{|c|}{ Phillips-Perron } \\
\hline Order of integration & Variable & Intercept & $\begin{array}{l}\text { Trend and } \\
\text { intercept }\end{array}$ & None \\
\hline Level & LGDP & -0.120 & -3.073 & 3.136 \\
\hline $1^{\text {st }}$ difference & DGDP & $-11.502^{\star \star \star}$ & $-11.489^{\star \star \star}$ & $-10.092^{\star \star \star}$ \\
\hline Level & LRER & -2.432 & -2.143 & -0.427 \\
\hline $1^{\text {st }}$ difference & DRER & $-7.591^{\star \star \star}$ & $-7.631^{\star \star \star}$ & $-7.651^{\star \star \star}$ \\
\hline Level & LRIR & -1.966 & -3.239 & -0.677 \\
\hline $1^{\text {st }}$ difference & DRIR & $-6.700^{\star \star \star}$ & $-6.657^{\star \star \star}$ & $-6.750^{\star \star \star \star}$ \\
\hline Level & LFCF & 0.149 & -1.327 & 3.135 \\
\hline $1^{\text {st }}$ difference & DFCF & $-6.198^{\star \star \star}$ & $-6.213^{\star \star \star}$ & $-5.419^{* \star *}$ \\
\hline Level & LMS & -1.707 & -4.762 & -0.041 \\
\hline $1^{\text {st }}$ difference & DMS & $-19.590^{\star \star \star}$ & $-21.247^{\star \star \star}$ & $-19.700^{\star \star \star}$ \\
\hline Level & LTO & -2.630 & -2.660 & 0.200 \\
\hline $1^{\text {st }}$ difference & DTO & $-10.244^{\star \star \star}$ & $-10.327^{\star \star \star}$ & $-10.276^{* \star \star}$ \\
\hline $1 \%$ & \multirow{3}{*}{ Critical values } & -3.532 & -4.101 & -2.600 \\
\hline $5 \%$ & & -2.906 & -3.478 & -1.946 \\
\hline $10 \%$ & & -2.590 & -3.167 & -1.614 \\
\hline
\end{tabular}

Table 1 shows the Augmented Dickey-Fuller results. The test has a null hypothesis of unit root. The calculated value of ADF was compared with the critical value. If the calculated value is greater than the critical, we then reject the null hypothesis that the series have unit root, thus confirming that the series are stationary. The ADF tests variables in (a) 
intercepts, (b) trends and intercepts and (c) no trend and no intercept. For variables in levels, the test in intercepts revealed that all variables were not stationary. For the intercept, all the data in levels was not stationary as reflected by the non-rejection of the null hypothesis at both $1 \%$ and $5 \%$ significance levels. All the differenced variables were stationary at $1 \%$ significant level; hence the null hypothesis of unit root is rejected. For the test under trend and intercept and trend and no intercept data series were all non-stationary in levels but became stationary at $1 \%$ significant level when first differenced.

Table 2 shows the Phillips-Peron results. According to Brooks (2008) the tests are similar to ADF tests, but they incorporate an automatic correction to the DF procedure to allow for auto correlated residuals. For variables in levels, the test in intercepts revealed that none of the variables were stationary. All differenced variables on intercept were stationary at $1 \%$ significance level. On trend and intercept all variables were non-stationary in levels but all variables on trend and intercept were stationary at $1 \%$ significance level when first differenced. For the test under no trend and no intercept, all variables in levels were non-stationary. When first differenced, all the variables were stationary at $1 \%$ significance.

Both methods used to test for stationarity significantly revealed that the data series were non-stationary in levels and stationary when first differenced. Therefore, the series are integrated of the same order I(1).

\subsection{Tests for cointegration}

Since all the variables are integrated of the same order, it is very important to determine whether there exists a long-run equilibrium relationship amongst them. For the purposes of this study cointegration examines the long run relationship between the gross domestic product and its determinants. Since all variables are non-stationary in level, the next procedure is to test for the existence of long run relationships among the variables in the model. The cointegration test using Johansen test requires the estimation of a VAR equation. The variables i.e. LnRER, LnRIR, LnMS, LnOP, and LnFCF are entered as endogenous variables.

The information criteria approach is applied in this study as a direction to choose the lag order. It is a requirement of the Johansen technique to show an indication of the lag order and the deterministic trend assumption of the VAR. Table 3 confirms the lag lengths selected by different information criteria.

Table 3: Lag order selection criteria

\begin{tabular}{|c|c|c|c|c|c|c|}
\hline Lag & LogL & LR & FPE & AIC & SC & HQ \\
\hline 0 & 321.7273 & NA & $1.79 \mathrm{e}-12$ & -10.02309 & -9.818982 & -9.942813 \\
\hline 1 & 734.9081 & 734.5437 & $1.13 \mathrm{e}-17$ & -21.99708 & $-20.56833^{\star}$ & -21.43515 \\
\hline 2 & 788.9004 & 85.70206 & $6.60 \mathrm{e}-18$ & -22.56827 & -19.91486 & -21.52467 \\
\hline 3 & 820.3785 & 43.96931 & $8.25 \mathrm{e}-18$ & -22.42471 & -18.54666 & -20.89946 \\
\hline 4 & 892.3342 & 86.80379 & $3.09 \mathrm{e}-18$ & -23.56617 & -18.46346 & -21.55925 \\
\hline 5 & 951.8420 & $60.45229^{\star}$ & $1.95 \mathrm{e}-18^{\star}$ & $-24.31244^{*}$ & -17.98509 & $-21.82387^{\star}$ \\
\hline
\end{tabular}

Notes

* indicates lag order selected by the criterion

LR: sequential modified LR test statistic (each test at $5 \%$ level)

FPE: Final prediction error

AIC: Akaike information criterion

SC: Schwarz information criterion

HQ: Hannan-Quinn information criterion

Table 3 confirms that the criteria selected 5 lag. Consequently, using the information criteria approach, the Johansen cointegration test was conducted using 5 lag for the VAR.

The trace test results based on the Johansen cointegration are shown in Table 4. The null hypothesis of the trace test is that the number of co-integrating equations is greater than the number of variables involved. If the test statistic is smaller than critical values of the trace tests we do not reject the null hypothesis. Table 5 presents the results of the Johansen cointegration test based on the maximum eigenvalue. The maximum eigenvalue test was conducted on a null hypothesis of the number of cointegration equations $(r)$ against the alternative hypothesis of number of cointegration equations plus one $(r+1)$. We do not reject the null hypothesis if the test statistic is smaller than the maximum eigenvalue test's critical values. 
Table 4: Co-integration Rank Test (Trace)

\begin{tabular}{|c|c|c|c|c|}
\hline Hypothesised No. Of CE(s) & Eigenvalue & Trace Statistic & 0.05 Critical Value & Prob** \\
\hline None $^{*}$ & 0.615084 & 62.05753 & 40.07757 & 0.0001 \\
\hline At most 1 & 0.544707 & 33.87687 & 51.14299 & 0.0002 \\
\hline At most 2 & 0.330947 & 26.12297 & 27.58434 & 0.0760 \\
\hline At most 3 & 0.169760 & 12.09264 & 21.13162 & 0.5385 \\
\hline At most 4 & 0.078585 & 5.319883 & 14.26460 & 0.7010 \\
\hline At most 5 & 0.003438 & 0.223852 & 3.841466 & 0.6361 \\
\hline
\end{tabular}

Trace test indicates 1cointegratingeqn(s) at the 0.05 level

* denotes rejection of the hypothesis at the 0.05 level

**MacKinnon-Haug-Michelis (1999) p-values

Table 5: Co-integration Rank Test (Maximum Eigenvalue)

\begin{tabular}{|c|c|c|c|c|}
\hline Hypothesised No. Of CE(s) & Eigenvalue & Trace Statistic & 0.05 Critical Value & Prob $^{\star *}$ \\
\hline None $^{*}$ & 0.615084 & 156.9599 & 95.75366 & 0.0000 \\
\hline At most ${ }^{*}$ & 0.544707 & 94.90234 & 69.81889 & 0.0002 \\
\hline At most 2 & 0.330947 & 43.75935 & 47.85613 & 0.1151 \\
\hline At most 3 & 0.169760 & 17.63638 & 29.79707 & 0.5930 \\
\hline At most 4 & 0.078585 & 5.543734 & 15.49471 & 0.7487 \\
\hline At most 5 & 0.003438 & 0.223852 & 3.841466 & 0.6361 \\
\hline
\end{tabular}

Max-Eigen value test indicates 1 cointegration Eqn(s) at the 0.05 level

* denotes rejection of the hypothesis at the 0.05 level

**MacKinnon-Haug-Michelis (1999) p-values

Figure 4 shows the results of the trace test which reflect that at least one co-integrating equation exists at $5 \%$ significance level. The null hypothesis of no cointegration vectors is rejected since the trace (test) statistic of 62.057 is greater than the $5 \%$ critical value of approximately 40.077 . Using a similar explanation, the null hypothesis that there is at most 1 cointegration vector cannot be rejected since the test statistic of approximately 33.877 is less than the $5 \%$ critical value of about 51.143. For that reason, the trace statistics specified 1 co-integrating relationship at $5 \%$ significance level. The maximum Eigen value test in Table 5 put forward that there is only 1 cointegrating relationship in the gross domestic product model. The maximum Eigen value test also rejected the null hypothesis of no cointegration, but failed to reject that at most 1 co-integrating vectors exist, since the test statistic of about 43.759 is less than the $5 \%$ critical value of about 47.856. Therefore, it can be concluded that there is one significant long run relationship between the given variables (using the trace test). Since variables can either have short or long run effects, a vector error correction model (VECM) is used to disaggregate these effects.

Table 4 indicates the existence of one cointegration vector. The cointegration vector represents the deviations of the endogenous variable from its long run equilibrium level. Figure 4 (see Appendix 3) shows that over the period 1994 to 2010, the deviations of economic growth from equilibrium were stationary and this is critical in its use as an error correction model.

\subsection{Vector Error Correction Model (VECM)}

The detection of a cointegration equation in the previous section means that a VECM can be used. This has led to a distinction between the long and short run impacts of variables so as to establish the extent of influence that real exchange rates has on economic growth. Using the results from the cointegration test the VECM was specified. The VECM results are presented in Tables 6 and 7.

Table 6: Results of the long run cointegration equation

\begin{tabular}{|c|c|c|c|}
\hline Variable & Coefficient & Standard error & t-statistic \\
\hline Constant & -10.23693 & - & - \\
\hline LOG_GDP & 1.000000 & - & - \\
\hline LOG_RER & -0.163071 & 0.03974 & -4.10355 \\
\hline
\end{tabular}




\begin{tabular}{|c|c|c|c|}
\hline LOG_RIR & 0.091851 & 0.01127 & 8.15153 \\
\hline LOG_OP & -0.199206 & 0.05632 & -3.53710 \\
\hline LOG_MS & -0.257361 & 0.01814 & -14.1872 \\
\hline LOG_FCF & 0.124363 & 0.04866 & 2.55592 \\
\hline
\end{tabular}

The long run impact of real exchange rates on economic growth as presented in Table 5.5 is illustrated using Equation 5.1:

$\mathrm{GDP}=-10.237-0.163 \mathrm{RER}+0.092 \mathrm{RIR}-0.1990 \mathrm{P}-0.257 \mathrm{MS}+0.124 \mathrm{FCF} \ldots \ldots \ldots \ldots . . \ldots$

Equation 4 shows that RER, RIR and FCF have a positive long run relationship with GDP. On the other hand, MS and OP show a negative long run relationship with GDP. All the variables are statistically significant in explaining economic growth since they have absolute t-values greater than 2. The results suggest that a unit increase in RER which is a depreciation of the South African rand against its trading partners, reduces economic growth in the long run by approximately 0.163 . This shows that despite the fact that a negative relationship exists in the short run as depicted by Table 5.6 below; in the long run it is not sustainable. In the long run the results follow the Structuralist view to exchange rates which holds that depreciation might have a contractionary effect on output and employment, especially for less economically developed countries. Depreciation increases the cost of imports in particular, and the cost of domestic production in general, through imported inputs

In the long run a unit increase in RIR increases economic growth by approximately 0.092 . An increase in RIR in the long run attracts foreign direct investment especially portfolio investments which improves South Africa's balance of payments accounts thus increasing economic growth.

A unit increase in FCF increases economic growth in the long run by approximately 0.124 . Investment in public and private infrastructure like roads, plant and equipment expands the country's production capacities. This in turn guarantees increases in the gross domestic product of a country in the long run.

In this study, MS has a negative long run effect on economic growth. A unit increase in MS reduces economic growth by approximately 0.257 . An increase in MS in the long run can be inflationary and this has negative effects on economic growth. Lastly, OP was also found to be negatively related to economic growth. A unit increase in OP reduces GDP by approximately 0.199. Trade openness of South Africa to the whole world comes with its own disadvantages such as capital flight, effects of international financial instability, for instance global financial crises and the South East Asian crises of 1998 and 1999, the Zimbabwean crises and imported inflation. These factors contributed a great deal to the negative impact of OP on growth during the study period.

Table 7: Error correction model results

\begin{tabular}{|c|c|c|c|}
\hline Variable & Coefficient & Standard error & t-statistic \\
\hline D(LOG_GDP) & -0.139042 & $(0.15133)$ & -2.91882 \\
\hline D(LOG_RER) & 3.046736 & 1.10049 & 2.76853 \\
\hline D(LOG_RIR) & -12.02454 & 3.57355 & -3.36487 \\
\hline D(LOG_OP) & 0.414884 & 0.58940 & 0.70390 \\
\hline D(LOG_MS) & -0.120453 & 0.28205 & -0.42707 \\
\hline D(LOG_FCF) & -0.486794 & 0.33937 & -1.43441 \\
\hline
\end{tabular}

In Table 7, the coefficient of D (LOG_GDP) of -0.139 shows that the speed of adjustment is approximately 13.9 percent. This means that if there is a deviation from equilibrium, only 13.9 per cent is corrected in one quarter as the variable moves towards restoring equilibrium. This means that there is no strong pressure on economic growth to restore long run equilibrium whenever there is a disturbance. This speed of adjustment is statistically significant with an absolute t-value of approximately 2.91882. The low speed of adjustment by economic growth may reflect the existence of some other factors affecting economic growth in South Africa which are not specified in the model.

In the short run as illustrated in Table 7, it can be noted that the real exchange rate has a negative effect on growth. A unit increase in real exchange rates which is a depreciation of the South African rand increases economic growth by approximately 3.046. This is compatible with the traditional approach to exchange rates which holds that devaluations have expansionary effects on economic growth. Depreciation of a currency will cause local goods to be cheaper abroad and this will increase their demand leading to an increase in exports thereby improving the trade balance and accordingly expand output and employment. Depreciations may in some cases be a quick fix in the short run, but not sustainable in the long run. As is the case in this study, in the long run the relationship becomes positive. 
Real interest rates in the short run have a negative impact on growth. An increase in RIR reduces growth by approximately 12.024. An increase in the real interest rates in the short run increases the cost of borrowing thereby dampening investment in the country, leading ultimately to a decrease in gross domestic product in the short run. In the long run, it is different as high interest rates helps in keeping price stability and low inflation which in turn improves growth prospects.

Real exchange rates and real interest rates are statistically significant in explaining economic growth in South Africa in the short run as seen by absolute t-values of above 2 . The other variables FCF, OP and MS have insignificant tvalues of below 2 .

\subsection{Diagnostic Checks}

The economic growth model was subjected to thorough diagnostics tests. The model was tested for normality, serial correlation, autoregressive conditional heteroscedasticity and stability. Diagnostic checks are performed to the GDP modeling in order to validate the parameter evaluation of the outcomes achieved by the model. Any problem in the residuals from the estimated model makes the model to be not efficient and the estimated parameters will be biased. For the purposes of this study, the VAR model was subjected to diagnostic checks. The diagnostic test results are presented in Table 8 below and these assist in checking for serial correlation, normality and heteroscedasticity. These diagnostic checks are based on the null hypothesis that: there is no serial correlation for the LM test; there is normality for the Jarque-Bera test and there is no heteroscedasticity for the White heteroscedasticity test.

Table 8: Diagnostic checks results

\begin{tabular}{|l|l|c|c|}
\hline \multicolumn{1}{|c|}{ Test } & \multicolumn{1}{c|}{ Null Hypothesis } & t-Statistic & Probability \\
\hline Langrage Multiplier (LM) & No serial correlation & 17.450 & 0.634 \\
\hline White (CH-sq) & No conditional heteroscedasticity & 0.875 & 0.489 \\
\hline Jarque-Bera (JB) & There is a normal distribution & 5.737 & 0.056 \\
\hline
\end{tabular}

Results from Table 8 show that the test for serial correlation produced an LM statistic of 17.450 with a probability of 0.634 . For the Histogram and Normality Test, Jarque-Bera is 5.737 and the probability is 0.056 . Thus, the Jarque-Bera statistic is insignificant as it is above the 5 percent significance level. More so, the histogram is bell-shaped, thus, the residuals are normally distributed. Therefore, the null hypothesis of a normal distribution was not rejected. Heteroscedasticity tests showed the F-statistic of 0.875 and the probability of 0.489 which means that the null hypothesis of no heteroscedasticity was accepted. The alternative hypothesis was that there is heteroscedasticity. This means that the residuals are homoscedastic. The results for the diagnostic checks for serial correlation and heteroscedasticity show that the data is fairly well behaved. Results indicate the presence of non-normal residuals.

\subsection{Impulse Response Analysis}

Impulse response analysis traces out the responsiveness of the dependent variables in a VAR to shocks from each of the variables (Brooks 2008). Results of the impulse response analysis are presented in Figure 5 (see appendix 4).

Since this study focuses on the impact of real exchange rates on economic growth, only the responses of economic growth to real exchange rates and the responses of economic growth to economic growth are reported in Figure 5. These impulse response functions show the dynamic response of economic growth to a one-period standard deviation shock to the innovations of the system and also indicate the directions and persistence of the response to each of the shocks over 10 quarters. For the most part, the impulse response functions have the expected pattern and confirm the results from the short run relationship analysis. Shocks to all the variables are significant although they are not persistent. Shock to the FCF, OP and MS have an enormous dampening impact on economic growth. In the long run this effect seems to be reversed. A RER shock will have a positive impact on economic growth except for the first two quarters and the $8^{\text {th }}$ quarter onwards where there is a negative impact. Shocks to MS show a very turbulent nature for example in the first two quarters, a shock to MS shows a dampening effect on growth. From the second quarter, shocks to MS have positive effect to growth until 2.5 quarters were it reaches equilibrium and continues growing positive until the $5^{\text {th }}$ quarter then turns negative again from the $6^{\text {th }}$ quarter to the $8^{\text {th }}$ quarter were it turns positive again. Shocks to MS from the $8^{\text {th }}$ quarter to the $10^{\text {th }}$ quarter take a negative effect on growth. 


\subsection{Variance Decomposition Analysis}

Variance decomposition analysis provides a means of determining the relative importance of shocks in explaining variations in the variable of interest (Andren, 2007). Variance decomposition provides a way of determining the relative importance of shocks to real exchange rates in explaining variations in economic growth. The results of the variance decomposition analysis are presented in Table 9 and these show the proportion of the forecast error variance in economic growth as explained by its own innovations and innovations in real exchange rates.

Table 9: Variance decomposition of GDP

\begin{tabular}{|c|c|c|c|c|c|c|c|}
\hline Period & S.E & LOGGDP & LOGRER & LOGRIR & LOGOP & LOGMS & LOGFCF \\
\hline 1 & 0.022530 & 100.0000 & 0.000000 & 0.000000 & 0.000000 & 0.000000 & 0.000000 \\
\hline 2 & 0.027007 & 88.42171 & 0.018915 & 5.021784 & 5.027464 & 0.028820 & 1.481311 \\
\hline 3 & 0.028071 & 87.64746 & 0.092347 & 5.773033 & 4.663513 & 0.050707 & 1.772944 \\
\hline 4 & 0.029311 & 87.87705 & 0.085513 & 5.395342 & 4.334555 & 0.067604 & 2.239933 \\
\hline 5 & 0.031396 & 88.80387 & 0.170496 & 5.061382 & 3.778293 & 0.103042 & 2.082911 \\
\hline 6 & 0.033063 & 88.49551 & 0.191862 & 5.489679 & 3.631355 & 0.131207 & 2.060387 \\
\hline 7 & 0.034327 & 88.65880 & 0.181087 & 5.536713 & 3.378323 & 0.147839 & 2.097243 \\
\hline 8 & 0.035546 & 88.89307 & 0.171688 & 5.422261 & 3.152349 & 0.162573 & 2.198058 \\
\hline 9 & 0.036880 & 89.16606 & 0.170898 & 5.356722 & 2.934238 & 0.179910 & 2.192168 \\
\hline 10 & 0.038141 & 89.26224 & 0.172740 & 5.409653 & 2.772700 & 0.195378 & 2.187284 \\
\hline
\end{tabular}

Since this study focuses on the movements of economic growth following shocks to itself or real exchange rates, the study reports only the variance decomposition in economic growth and it analyses the relative importance of real exchange rates in influencing its movements.

The study allows the variance decompositions for 10 quarters in order to ascertain the effects when the variables are allowed to affect economic growth for a relatively longer time. In the first quarter, all of the variance in economic growth is explained by its own innovations (shocks), as suggested in Brooks (2008). For the 5th quarter ahead forecast error variance, reported in column 2 of Table 9 under S.E., economic growth itself explains about 88 per cent of its variation, while the other variables explain only the remaining 12 per cent. Of this RER explains 0.17 per cent, RIR explains about 5.1 per cent, OP explains 3.8 per cent, MS explains 0.10 and FCF explains about 2.08 per cent.

However, after a period of 10 quarters, economic growth explains about 89 per cent of its own variation, while other variables explain the remaining 11per cent. The influence of RER was still at 0.17 per cent, while RIR increased to about 5.4 per cent, OP decreased to 2.8 per cent, MS increased to 0.19 and FCF increased to about 2.19 per cent. These results are similar to those from the impulse response analysis in that all the variables have a significant impact on economic growth in the short run.

Economic growth explains most of its variations, followed by real interest rates and then trade openness and fixed capital formation. Money supply and real exchange rates though significant, do not explain much of the variations in economic growth. Using the variance decomposition analysis it can be seen that real interest rates are a very important variable in explaining economic growth in South Africa over the study period.

\section{Conclusions and Policy Recommendations}

Results in this study have a number of policy implications. This section divides them into exchange rate policy, investment policy, trade policy and monetary policy.

\subsection{Exchange Rate Policy}

The long run results as presented in table 6 suggested that real exchange rates have a negative impact on economic growth. The coefficient of RER from the long run equation suggested by VECM results implies that a unit rise in South Africa's real exchange rates leads to a 0.163 percentage point decrease in economic growth in the country. Results from the short run equation however, shows that a unit rise in South Africa's real exchange rates leads to a 3.046 percentage point increase in economic growth in the country.

In this regard, for South Africa to increase economic growth, the policy of devaluating the currency can only work 
in the short run. Based on the short run relationship, depreciation increases growth but this can be seen only as a quick fix that has negative consequences in the long run. In the long run a depreciation/devaluation can only reduce economic growth; hence depreciation/devaluation works well in the short run but has negative consequences in the long run. Based on these finding the policy of depreciation to increase exports and growth in the economy might not be the best policy for South Africa. In order to avoid misalignments (overvaluation or undervaluation of the rand) the best policy is to leave the determination of exchange rates to the forces of demand and supply, were the rand exchange reverts to its own equilibrium.

\subsection{Investment policy}

Estimation results in this study revealed that investment expenditure has a positive impact on economic growth in South Africa in the long run, that is, a unit increase in fixed capital formation leads to a 0.124 increase in economic growth. The implication for policy is that the government should spend more on investment in order to improve economic growth in the country. The government should invest in infrastructure; roads, plant and equipment, hospitals. The government should also invest in human capital through educating its people. The returns to investment are not immediate as revealed by the short run results in Table 7. In the short run the impact of investment on growth is negative; however the impact is positive and significant in the long run. The rationale being that in the short run it is not easy to recoup some of the costs incurred in investments of both physical and human capital, but in the long run the returns to investment will be high. In order to achieve high levels of economic growth in the long run, the government has to invest heavily though the returns are not so high in the short run.

\subsection{Monetary Policy}

Estimation results in this study revealed that money supply has a negative impact on economic growth in South Africa both in the short run and long run. From the long run equation, a unit increase in money supply reduces growth by approximately 0.257 . Long run results also suggest that a unit increase in real interest rates increases growth by approximately 0.0912 . In the short run increase in real interest rates reduce growth by approximately 0.120 . The implication for policy is that in the short run an expansionary monetary policy is effective. This implies that a reduction on a repo rate can induce investments thereby improving economic growth. However, the effects of a contractionary monetary policy can be experienced only in the long run.

Furthermore, taking into account the impulse response analysis and variance decomposition analysis, it can be seen that real interest rates explain much of the variations in economic growth. Interest rates therefore are a very important tool in influencing economic growth in South Africa. The policy framework currently being used by the central bank of inflation targeting is relevant and effective in the current South African economic climate. The government uses repo rate to control both money supply and inflation. Given the long run relationship and the variance decomposition analysis, the researcher recommends that the current monetary policy in South Africa be maintained.

\subsection{Trade Policy}

Estimation results in this study revealed that in the short run trade openness increases economic growth in South Africa by approximately 0.415 . From the long run equation though, a unit increase in openness reduces growth by approximately 0.199 . For trade openness to be successful, there are many factors to be taken into consideration; terms of trade, trade diversification, balance of trade and the nature of goods imported and exported. In order for trade openness to be sustainable and profitable in the long run, South Africa has to diversify trade. The over reliance on primary produce such as mining and agriculture products reduces the gains from trade. There is need to diversify into value addition products which fetch high price at the world market, for instance, the need to expand the already viable car manufacturing industry and other value adding industry. South Africa should also improve on the service industry in order to compete with developed countries.

South Africa should also increase the import reducing measures in order to protect and expand local industry. This can be done by imposing import tariffs and export subsidies. This increases domestic demand for local industry and making them stronger in order to compete with international industries in the long run, thus improving trade balance and ultimately economic growth. 


\section{References}

Acar, M. (2000). Devaluation in Developing Countries: Expansionary or Contractionary? Journal of Economic and Social Research, 2 (1).

Aguirre, A., and Calderon, C. (2005). Real Exchange Rate Misalignments and Economic Performance. Central Bank of Chile, Working Paper 315

Akpan, P.L. (2008). Foreign Exchange Market and Economic Growth in an Emerging Petroleum Based Economy: Evidence from Nigeria (1970-2003). African Economic and Business Review, 6 (2).

Andren, T. (2007). Econometrics. United Kingdom: Thomas Andren \& Ventus publishing ApS.

Brooks, C. (2008). Introductory Econometrics for Finance. Cambridge: Cambridge University Press.

Chen, J. (2012). Real Exchange Rate and Economic Growth: Evidence from Chinese Provincial Data (1992-2008). Paris School of Economics, France, Working paper 2012-05.

Department of Trade and Industry (DTI). (2012). Research Statistics. [Online], Available: http//tradestats.thedti.gov.za /ReportFolders.aspx/sCS. [Accessed 14 August 2012].

Domac, I., and Shabsigh, G. (1999). Real Exchange Rate Behaviour and Economic Growth: Evidences from Egypt, Jordan, Morocco and Tunisia. IMF Working Paper, WP/99/40.

Du Plessis, S., and Smit, B. (2007). South Africa's Growth Revival after 1994. Stellenbosch Economic Working Papers 01/06.

Edwards, L., and Garlick, R. (2007). Trade Flows and the Exchange Rate in South Africa. Trade and Policy Strategies. Working Paper.

Gujarati, D.N., and Porter, C.D. (2010). Essentials of Econometrics 4th ed. New York: McGraw-Hill International Edition.

Jaussaud, J., and Rey, S. (2009). Long-Run Determinants of Japanese Exports to China and the United States: A Sectoral Analysis. University of Pau, France. Working Paper.

Johansen, S. (1991). Estimation and Hypothesis testing of Cointegration Vectors in Gaussian vector Autoregressive Models. Econometrica, 59.

Johansen, S. (1995). Likelihood-based Inference in Cointegrated Vector Autoregressive Models. Oxford: Oxford University Press.

McDonald, R. (2000). The Role of the Exchange Rate in Economic Growth: a Euro-zone Perspective. National Bank of Belgium. Working Paper 09.

McPherson, M.F., and Rakovski, T. (2000). Exchange Rates and Economic Growth in Kenya: An Econometric Analysis. African Economic Policy: Discussion Paper 56.

Mishi, S. (2011). Real Exchange Rate Misalignment and Economic Growth: Empirical Evidence from South Africa. Nedbank budget speech competition South Africa [Online], Available: http://www.budgetspeechcompetition.co.za [Accessed 23 September 2011].

Montiel, P.J., and Serven, L. (2008). Real Exchange Rates, Savings and Growth: Is there a link? The World Bank, Development Research Group, Macroeconomic and Growth Team. Policy Research Working Paper WPS4636.

Munthali, T., Simwaka, K., and Mwale, M. (2010). The Real Exchange Rate and Growth in Malawi: Exploring the Transmission Route. Journal of Development and Agricultural Economics, 2(8).

Nchimunya, H. (2011). Does a Weaker Exchange Rate Make Sense? Nedbank budget speech competition South Africa [Online], Available: http://www.budgetspeechcompetition.co.za [Accessed 23 September 2011].

Razin, O., and Collins, M. (1997). Real Exchange Rate Misalignments and Growth. NBER Working Paper 6174.

Rodrik, D. (2007). The Real Exchange Rate and Economic Growth: Theory and Evidence. Kennedy School of Government Harvard University Cambridge. Working Paper.

Rodrik, D. (2008). The Real Exchange Rate and Economic Growth. Kennedy School of Government Harvard University Cambridge. Working Paper MA 02138.

Salvatore, D. (2005). The Euro-dollar Rate Defies Prediction. African Journal of Policy Modeling, 27(4).

SARB.(2012).HistoricMacroeconomicInformation[Online],Available:http://www.resbank.co.za/Research/Statistics/Pages/OnlineDownloa dFacility.aspx. [Accessed 14 August 2012].

Takaendesa, P. (2006). The Behaviour and Fundamental Determinants of the Real Exchange Rate in South Africa. Unpublished Master's Thesis. Rhodes University.

Tarawalie, B. (2010). Real Exchange Rate Behaviour and Economic Growth: Evidence from Sierra Leone. SAJEM 13(1).

Van der Merwe, E.J. (1996). Exchange Rate Management Policies in South Africa: Recent Experience and Prospects. South African Reserve Bank. Occasional Paper.

Walters, S., and De Beer, B. (1999). An Indicator of South Africa's External Competitiveness. South African Reserve Bank Quarterly Bulletin, September 1999.

Williamson, J. (2004). A Short History of the Washington Consensus. A Paper commissioned by Foundation CIDOB for a conference "From the Washington Consensus towards a new Global Governance," Barcelona, September 24-25, 2004.

\section{Appendices}

\section{Appendix 1}

Figure 2: Plots of variables in levels for $1994-2010$ 


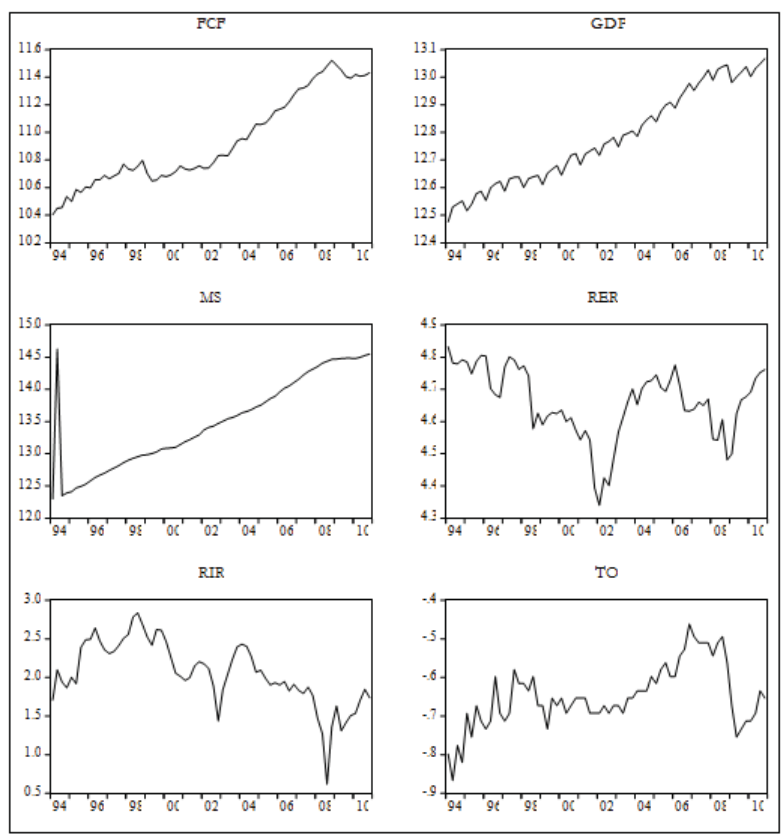

\section{Appendix 2}

Figure 3: Plots of first differenced variables for 1994-2010

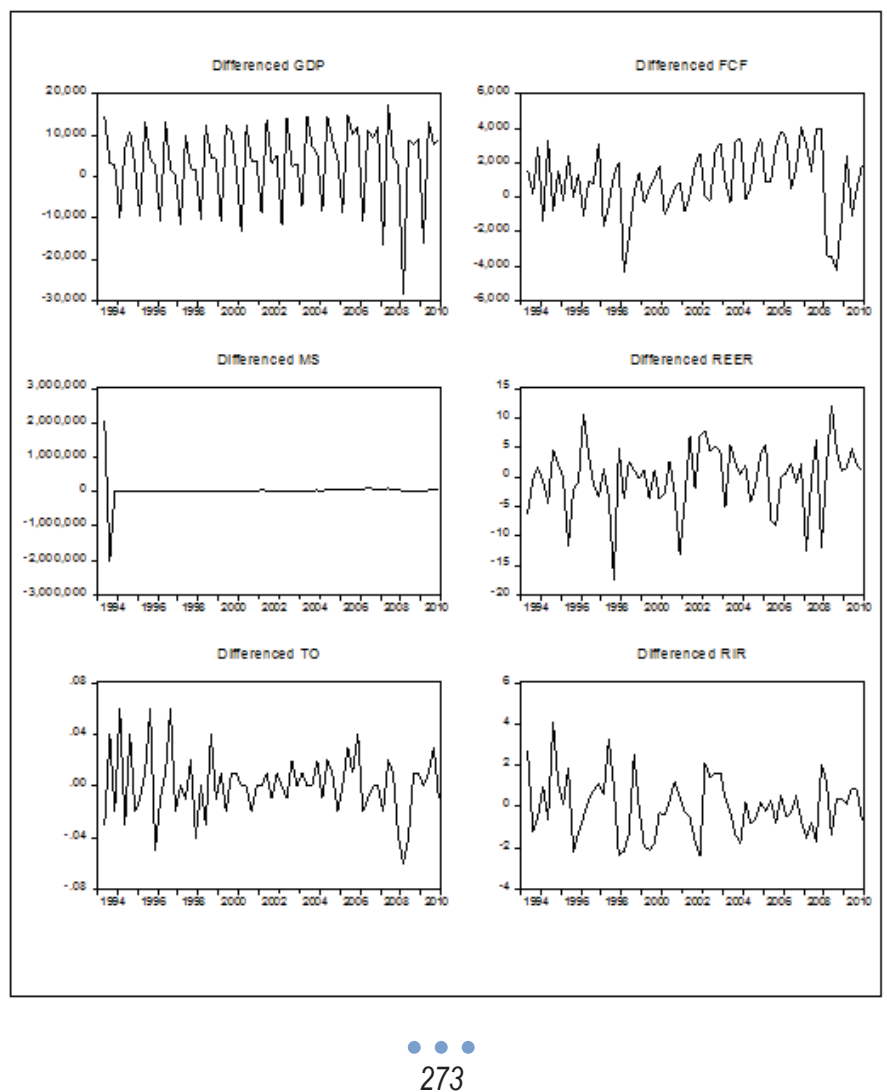




\section{Appendix 3}

Figure 4: Cointegration vector

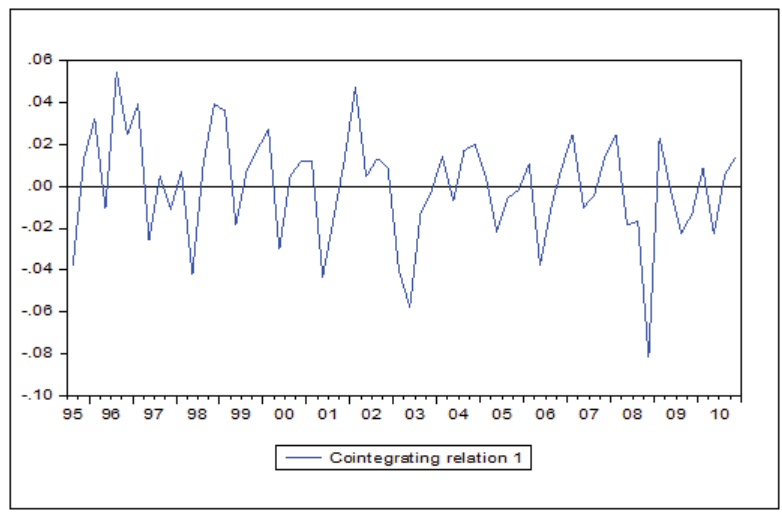

\section{Appendix 4}

Figure 5: Impulse response of GDP

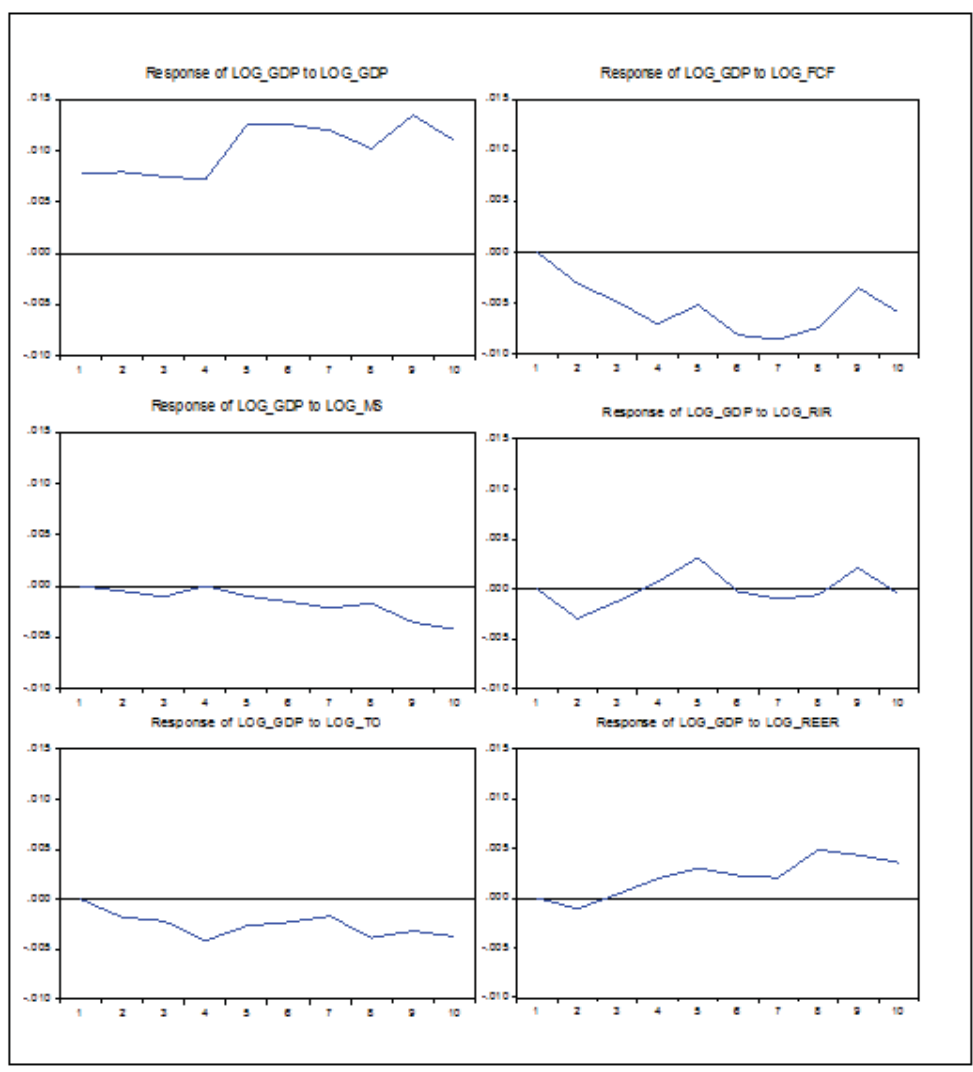

